\title{
Potyó István
}

\section{BERTHA BRUKENTHAL: EGY ARISZTOKRATA AZ ERDÉLYI ZENESZERZŐI TÉRBEN}

\author{
Kulcsszavak: Bertha Brukenthal, Erdély, egyházi zeneművek, cecilianizmus, F-dúr Missa \\ Solemnis
}

\section{ÉLETRAJZI ADATOK}

A Bertha Brukenthal néven ismertté vált zeneszerző 1846. március 14-én, Bécsben született a Czekelius von Rosenfeld nemesi családban. A família tartózkodási helye az osztrák fóváros volt ugyan, de erős szálak füzték Erdélyhez is, az elődök között számontartottak egy szebeni polgármestert, Johann Friedrich Czekeliust (1739-1809) és egy császári tanácsost is, Karl Ludwig Czekeliust (1804-1869). A tanulmány szerzője e Nagyszebenhez és az erdélyi szász arisztokrácia 19. századi zenekultúrájához kötődő témával adózik egykori mentora, doktori tanulmányai első vezetője, László Ferenc zenetudós emléke előtt. Bertha baronesse a kor nemesi gyakorlatának megfelelően már gyermekként zenei nevelésben részesült, előbb zongorázni, majd hegedülni tanult. Forrásaink arra utalnak, ${ }^{1}$ hogy Julius Epstein (1832-1926) ${ }^{2}$ zongoraiskolájában tanult. Komponistaként a bárónő a leggyakrabban az énekhangra és zongorára írott dal müfaját gyakorolta, 25 opusa közül 17 ezt a műfajt képviseli. A zeneszerző vonzódása a liedhez azzal is magyarázható, hogy énekelni Betty Bury ${ }^{3}$ énekmúvésztől tanult. Bertha Brukenthal alkotásai többségét nemesi családok tagjainak, valamint kortárs múvészeknek, múvészetpártolóknak ajánlotta, ez egyrészt kapcsolatteremtő képességét jelzi, másrészt művei értékét is behatárolja.

1865. október 26-án Bertha Czekelius von Rosenfeld házasságot kötött Hermann Carl Josef (Ármin Károly József) von Brukenthallal. A házasság rövid ideig tartott a férj korai halála miatt, mely hét évvel a házasságkötésük után, 1872. március 19-én következett be. Hermann Brukenthal, a család utolsó férfiági leszármazottja életéről igen kevés adattal rendelkezünk. Csáki Mihály (a Brukenthal Múzeum 1892-1927 közötti őre) szerint „életszerető, jólelkű ifjú volt (...), talán bohém természetű, a megszokottól ugyancsak eltérő életvitel jelle-

* Potró István (1983), egyházzenész, a kolozsvári Szent Mihály-templom kántora. E-mail: potyo. istvan@ceciliakorus.ro.

1 Isolde Weiermüller-Backes: Brukenthal Bertha. http://www.certosaverlag.de/bio.php?c=226. (Utolsó megtekintés: 2019. máj. 14.)

2 Julius Epstein Zágrábban született, és zongoristaként debütált Bécsben 1852-ben, később pedig Bécs egyik legkedveltebb zongoramúvészévé vált. Több mint harminc évig volt a Bécsi Konzervatórium tanára, Ignaz Brüll és Gustav Mahler a tanítványai közé tartozott.

3 Ismert bécsi múvésznő, Hector Berlioz Romeo és Júlia drámai szimfóniája bemutatóján 1846-ban a szólórészt ő énekelte. Lásd: http://www.hberlioz.com/Germany/viennapress.htm. (Utolsó megtekintés: 2019. máj. 4.) 
mezte”. Hermann Brukenthal Szebenben és Segesvárt tanult, később mezőgazdasági tanulmányokat folytatott Grazban. ${ }^{4}$

Férje tragikus halála után Brukenthal bárónő visszatért Ausztriába, és folytatta zenei tanulmányait. Művei számottevő földrajzi elterjedtségéből és mennyiségéből következtetünk arra, hogy ismertté vált kora zeneszerzői világában. (Szülőhazájába való visszatérése azzal is magyarázható, hogy Samuel von Brukenthal végrendelete értelmében, amennyiben a család férfiágon örökös nélkül marad, a vagyon nagy része az evangélikus egyházra száll.) Bertha Brukenthal Bécstől 35 kilométernyire, a mai Ausztria keleti részén, Gainfarn im Badenban hunyt el 1908. június 18-án.

A bárónő 33 éves volt, amikor a ma a szebeni Brukenthal Múzeumban fellelhető portréja, Rosa Schweniger múve készült. Férje képét a bécsi Friedrich von Amerling (1803-1887) festette, aki egy időben Szebenben múködött.

\section{BERTHA BRUKENTHAL ZENEI ÉLETMÚVE}

A Bertha Brukenthal által múvelt zenei múfajok három csoportba rendezhetók, énekhangra és zongorára írt dalok, kísérettel ellátott vagy a capella kórusművek és rövid hangszeres darabok. A zeneszerző munkái túlnyomó többsége lied, ezt a tényt a bárónő személyes affinitása mellett a müfajnak a korszakban érvényesülő - és különösen a nemesi családok kulturális életére jellemző - népszerűsége is magyarázza. Ha ehhez hozzáadjuk a három zongoradarabot és a két, vonósokra és zongorára írott duót, a kamaramúvek teljes tablóját kapjuk, amely az alkotó életművének zeneszerzői törzsanyagát képezi. A kórusmúvek két kategóriát képviselnek a szöveg laikus vagy vallásos jellege szerint, e felosztás értelmében a laikus textusra írt kórusmúvek az a capella technikával készültek, az egyházi szövegú kórusokhoz pedig hangszeres kíséret járul.

Az egyház köreiben használt és patronált múfajok mellett az arisztokrácia részvétele a 19. században a zeneművészet gyakorlásában és támogatásában rendkívüli jelentőségű volt. Bertha Brukenthal művei nagy részét az osztrák uralkodó osztály egyes személyiségeinek ajánlotta. E művek ajánlásai valószínúleg szerepet játszottak a családok közti jó viszony fenntartásában, elmélyítésében, egyszersmind hozzájárultak alkotójuk motivációjához és népszerüségének növekedéséhez. A szerző által tisztelettel övezett, dedikációra érdemes személyek között említhetők az arisztokrácia tagjai - Montenuovo-Batthyány Júlia grófnő, Pálffy Melanie grófnő, Bertha Kolowrat grófnő, Marie Kress von Kressenstein bárónő, II. Ernő herceg - és polgári címzettek egyaránt: Francesco Pandolfini (olasz bariton), Otto Müller (kántor, zeneszerző, pedagógus), Haynald József (kalocsai érsek), Rosa Schweninger (festő). ${ }^{5}$

Bertha Brukenthal munkáinak korabeli értékelése kitűnik abból is, ahogyan nyomtatásban megjelentek - ehhez kapcsolódóan néhány észrevételt kívánunk megfogalmazni. II. Ernő szász-coburg-gothai herceg (1818-1893) karizmatikus uralkodó volt, akinek gyermekkorá-

4 „Un tânăr iubitor de viaţă, bun la suflet (...), o fire probabil boemă care a dus o viaţă puţin conformistă”. Iulia Mesea: Mostenirea Baronului Samuel von Brukenthal. Revista Transilvania, Sibiu, 2003. 8. (Ford. E. E.)

5 Dr. Rita Fischer: Bertha von Brukenthal (1846-1908). http://www.edition-musik-suedost.de/ html/brukenthal.html. (Utolsó megtekintés: 2019. máj. 4.) 
ban sokoldalú nevelésben volt része, és aki felnőttként figyelmet fordított hercegségében a nevelési rendszerekre, a színházra, a művészeti gyưjteményekre és a könyvtárakra. A művészetek és a nevelés területei mellett különösen nagyra értékelte a kórusművészetet. Közbenjárására jött létre Coburgban a Deutsche Sängerbund (Német Kórusegyesület), amelynek 41 tagozata volt, és amely 45300 énekest fogott össze Németország, Ausztria, Anglia, Franciaország és Oroszország területéről. ${ }^{6}$ II. Ernő uralkodóként támogatta a kóruskultúra fejlődését, ez abban is megnyilvánult, hogy anyagilag elősegítette egyes kórusművek kiadását. A herceg nagylelkű hozzájárulásának köszönhetően, neki ajánlva látott napvilágot Bertha Brukenthal hat férfikari a capella műve (op. 14) is. Az, hogy a fent említett művek kiadója 1873-ban Lipcsében a Breitkopf\&Härtel volt, jelzi, mennyire értékelték az énekkarok a zeneszerző művészetét. Az itt publikált művek a következők:

1. Fischerlied. Abend zieht gemacht heran

2. Schlaf auch Du! Die Sonne sank, der Abend nabt

3. Frühlingseinzug Die Fenster auf! Die Herzen auf!

4. Ibr stolzen Sternchen

5. Meeresabend Sie hat den ganzen Tag getobt

6. Lied vom Winde Sausewind! Brausewind!

Valamennyi felsorolt darab előadói apparátusa: férfikar, két tenor és két basszus szólista.

A hangszeres kamarazenei repertoárt öt művel bővítette Bertha Brukenthal, közös nevezőjük a 19. század vége legnépszerúbb hangszerének, a zongorának használata. Ami a darabok létrejöttének idejét illeti, azt figyelhetjük meg, hogy a zeneszerző pályáján minden alkotói korszakban felbukkannak, 1867-től 1897-ig. Néhány mű címének eredetiségére is felfigyelhetünk: Cyclamen Walzer vagy Die Thalmaier Walzer, illetőleg a gyásztematikájúak: Il di dei morti, sőt ilyen az alkotó legelső műve is: Marche Funebre.

Zeneszerzői stílusukat tekintve az egyházzenei műfajú darabok a cecilianizmus - 19. századi mozgalom, melynek célja a római katolikus egyház zenei reformja - jellemzőit hordozzák. Nincs ehelyt lehetőségünk összehasonlítani az ekkor keletkezett múveket más múfajúakkal, konklúzióként azt fogalmazhatjuk meg, hogy azok a kompozíciós eljárások, amelyekkel Bertha Brukenthal élt, egyszerűek és átláthatóak, teljes összhangban a fent említett stílussal. E megállapítás alátámasztására a kórusmű címlapját mutatjuk be, a gyüjtemény Franz Schöpf (1836-1915) és Joseph G. Zangl (1821-1897) alkotásai mellett Bertha Brukenthal két vallásos kórusmúvét is tartalmazza. A Pange Lingua címú kórusdarab szigorú homofon szerkezetú, izoritmikus, különösebb nehézséget nem támaszt az előadóval szemben. A kiadót a dél-tiroli ceciliánus egyesület tartotta fönn. A címlap szerint a katolikus egyházi művek „im leicht ausfürbaren Kirchenstyle”, „hozzáférhető egyházi stílusban” íródtak.

A cecilianizmus hatását legnagyobb valószínűséggel a Habsburg Birodalom fôvárosára jellemző egyházzenei gyakorlat is magyarázza, továbbá az a tény, hogy Otto Müller (18371920), a Kirche am Hof udvari orgonistája irányítását élvezte. Otto Müller az augsburgi katedrális orgonistájának fia volt, alapos képzésben részesült, a müncheni konzervatóriumban ta-

6 Uő: Auf Spurensuche nach Bertha von Brukenthal (1846-1909) [Bertha Brukenthalra vonatkozó jegyek nyomában]. Musikzeitung. Mitteilungsblatt der Gesellschaft für Deutsche Musikkultur im Südostlichen Europa e. V. 2009, Heft 7., 12. 
nult, zenei tanulmányait aztán Franciaországban, majd Svájcban folytatta, 1915-ig a bécsi egyházzenei iskolában zeneelméletet oktatott. ${ }^{7}$

A Missa Solemnisen kívül Bertha Brukenthal életmúvében az egyházzenét egy orgonára és énekhangra írott, Hedwig Gatterburg bárónőnek ajánlott Ave Maria-ária (op. 10), két vegyeskarra komponált darab: egy Esz-dúr Offertórium, op. 11 és egy Pange lingua, op. 12 képviseli. Mindezeket, akárcsak a Missa Solemnist, az innsbrucki Gross Kiadóház publikálta 1877-ben.

Bertha Brukenthal zeneszerzői stílusa a bécsi zenei iskolára jellemző kiegyensúlyozott és átlátható szerkesztésre való céltudatos törekvés. Zenei nyelvezete a bécsi klasszika kompozíciós hagyományaiban gyökerezik. Azoknak a műveinek, amelyekhez hozzáfértünk, általános jegyük az egyszerűség, mely arra is utal, hogy alkotójuk tevékenységében a zenei alkotómunka másodrangúnak számított. A 19. század társadalmi kontextusában mégis figyelemre méltó tény, hogy a bécsi származású bárónő e nemes múvészetet különböző műfajok révén sikeresen múvelte.

\section{MISSA SOLEMNIS, F-DÚR, OP. $7^{8}$}

Bertha Brukenthal munkásságát áttekintve megállapítható, hogy az op. 7-es, F-dúr mise az egyetlen vokálszimfonikus alkotás, egyszersmind a szerző egyetlen nagyobb szabású múve. A mise 1871-ben készült, a komponista férje, Hermann von Brukenthal halálát megelőző esztendőben, minden valószínűség szerint ebben az időben Bertha von Brukenthal Erdélyben tartózkodott. A szerző szoros kötelékét a római katolikus egyházhoz az F-dúr mise és más darabjai, az e felekezethez kapcsolódó Ave Maria, a Pange Lingua és az Offertorium is jelzi. A komponista dedikációs gyakorlatát ismerve természetes gesztusnak tekinthető, hogy az F-dúr Missa Solemnis dedikációja dr. Haynald Lajos (1816-1896) kalocsai érseknek szól.

Haynald Lajos Esztergomban, Nagyszombatban és Bécsben tanult, 1839-ben szentelték pappá. 1851 és 1863 között az erdélyi egyházmegye püspöke volt, minden vallási és kulturális területen hozzáértésével és odaadásával tűnt ki. Nevéhez köthető több iskola és intézmény támogatása, többek között a ferences nővérek letelepítése Szebenben (1864). Erdélyi tartózkodása idején anyagilag támogatta a múvészeteket, saját vagyonából 400000 forintnyi összeget áldozott erre a célra. Érzékenységét bizonyítja a zene iránt az, hogy alapítványt hozott létre a kántorok megsegítésére, és hasonló tevékenységekre számtalan adományt folyósított. Életében számtalan zenekör, zenei alapítvány és szervezet tiszteleti tagjává választotta. Azok közül a zenészek közül, akikkel szoros kapcsolatban állt, Liszt Ferencet említjük. Az alábbi fénykép Haynald zenével kapcsolatos munkássága fél évszázados évfordulója alkalmával készült.

Haynald Lajos a szebeni zenei egyesület mentora is volt, az ő közbenjárásának köszönhetően publikálhatta Bertha Brukenthal munkáját a neves innsbrucki kiadónál. Ez a tény jelen-

7 Franz Metz: Bertha von Brukenthals „Missa Solemnis” wird in München aufgeführt (Bertha von Brukenthal Missa Solemnisa ismét felhangzik Münchenben). Siebenbürgische Zeitung 21. XII. 17. http://www.siebenbuerger.de. (Utolsó megtekintés: 2019. máj. 4.)

8 Külön köszönet illeti Franz Metz muzikológust a mise kottaanyagának közrebocsátásáért. 
tősen hozzájárult a mise elterjedéséhez a Habsburg Birodalom területén és a bárónő zenei hírneve növeléséhez. ${ }^{9}$

Noha címe a missa solemnis-típusba sorolja a művet, ez semmilyen tekintetben nem nyer megerősítést az illető alkotást megvizsgálva, a szókapcsolatnak inkább népszerűsítő szerepe van. A hangszerelés, a zenei diskurzus terjedelme, a szóló szólam hiánya és a forma egyszerűsége egyértelműen a missa brevis-típusra mutat. A mise együttese: vegyeskar, orgona, hegedúk, brácsa, gordonka és nagybőgő, két klarinét, két kürt váltakozva trombitákkal és üstdob. A partitúra a következő információkat emeli ki: Missa Solemnis in F für Sopran, Alt, Tenor, Bass, 2 Violinen, Viola, cello Basso, 2 Clarinette, 2 Horn abwechselnd mit Trompeten, u. Pauken, nebst ausgesekler Orgelstimme componirt und Sr. Excellenz dem Hochwürdichsten Herrn Erzbischof von Kalocsa Dr. Ludwig Haynald, k.k. wirkliche Geheimer Rath eleste ehgfurchtsvoll gewidmet von Baronin Bertha Brukenthal geborne Baronin Rosenfeld opus 7. Az együttes felállása a Wolfgang Amadeus Mozart és más klasszikus szerzők missa breviseivel, de a nagyvárosok egyházi énekzenekari gyakorlatával való hasonlóságot is sugallja. A rézfúvósok a mise részeinek megfelelően következnek egymás után, így a Kyrie, a Benedictus és az Agnus Dei esetén a szerző a kürtök hangzását használja, a Gloria, a Credo és a Sanctus esetén a trombitákét. Ez a differenciált megközelítés azt mutatja, hogy a szerző kereste a tényleges megfeleléseket a vallásos tartalom és a kifejezni kívánt érzelmek között. A mise harmonikus diskurzusa olyan viszonyokat mutat fel, amelyek jellemzőek a tonális-funkcionális szabályokra, a modulációk rokon hangnemekben valósulnak meg, a kadenciák többsége autentikus lévén, a harmónia váza így írható le:

\begin{tabular}{|c|c|c|c|c|c|c|}
\hline Tétel & Kyrie & Gloria & Credo & Sanctus & Benedictus & Agnus Dei \\
\hline Hangnem & $\mathrm{F} \sim \mathrm{C} \sim \mathrm{F}$ & $\mathrm{C} \sim \mathrm{a} \sim \mathrm{C}$ & $\begin{array}{c}\mathrm{G} \sim \mathrm{D} \sim \mathrm{G} \sim \\
\mathrm{g} \sim \\
\mathrm{G} \sim \mathrm{C} \sim \mathrm{G}\end{array}$ & $\mathrm{C}$ & $\mathrm{F} \sim \mathrm{d} \sim \mathrm{a} \sim \mathrm{F}$ & $\mathrm{f} \sim \mathrm{F}$ \\
\hline
\end{tabular}

1. táblázat. Bertha Brukenthal: Missa Solemnis in F, op. 7 (hangnemi elosztás)

A harmonikus szegmens szervezési elve a formák strukturális felépítésében ragadható meg.

Bertha Brukenthal Ruzitska György erdélyi egyházi zeneszerzőhöz hasonlóan Bécsben tanult, ebben a tekintetben sajátos hasonlóság figyelhető meg a Gloria és a Credo tételek megalkotásában. E két tételnek, amelynek üzenete szemantikai és liturgiai szempontból a legerősebb, hiányos a szövege, ezáltal liturgiai szempontból a komponista nem tartja tiszteletben az egyházi előírásokat. Amint az Ruzitska miséinél is megállapítható, ${ }^{10}$ a hiányos szöveghasználat elterjedt volt, különösen azoknál a zeneszerzőknél, akik olyan katolikus templomban tevékenykedtek, ahol gyakran mutattak be zeneműveket.

9 Franz Metz: Bertha von Brukenthal „Missa Solmenis” wird in München aufgeführt (Bertha von Brukenthal Missa Solemnise elhangzik Münchenben), Siebenbürgische Zeitung, 2010. dec. 21. http://www.siebenbuerger.de/zeitung/artikel/kultur/10658-bertha-von-brukenthals-missasolemnis.html. (Utolsó megtekintés: 2019. máj. 4.)

10 Pотүó István: Egy erdélyi egyházzenész, Ruzitska György elsó miséje = Erdélyiség a magyar zeneszerzők müveiben. Szerk. Hausmann Kóródy Alice. Partiumi Keresztény Egyetem, Nagyvárad, 2018. 127-154. 
A mise nyitótétele, a Kyrie lírai jellegű, a felső szólam diskurzusa könnyedén ellenpontozó. Ezekhez járul az F-dúr hangnem jellegzetes hangzása. A tétel 48 ütemből áll, három külön elemből megalkotott rész ez, a kezdő zenei szegmens változatlan megismétlése miatt a szonátaformához hasonlít. A következő zenei példa azt mutatja be, hogy a kíséretnek csak megkettőző és alkalomszerúen hangszínbeli szerepe van. Az első periódus két frázisának rögzülése a tenor hangjának késleltetésével valósul meg:

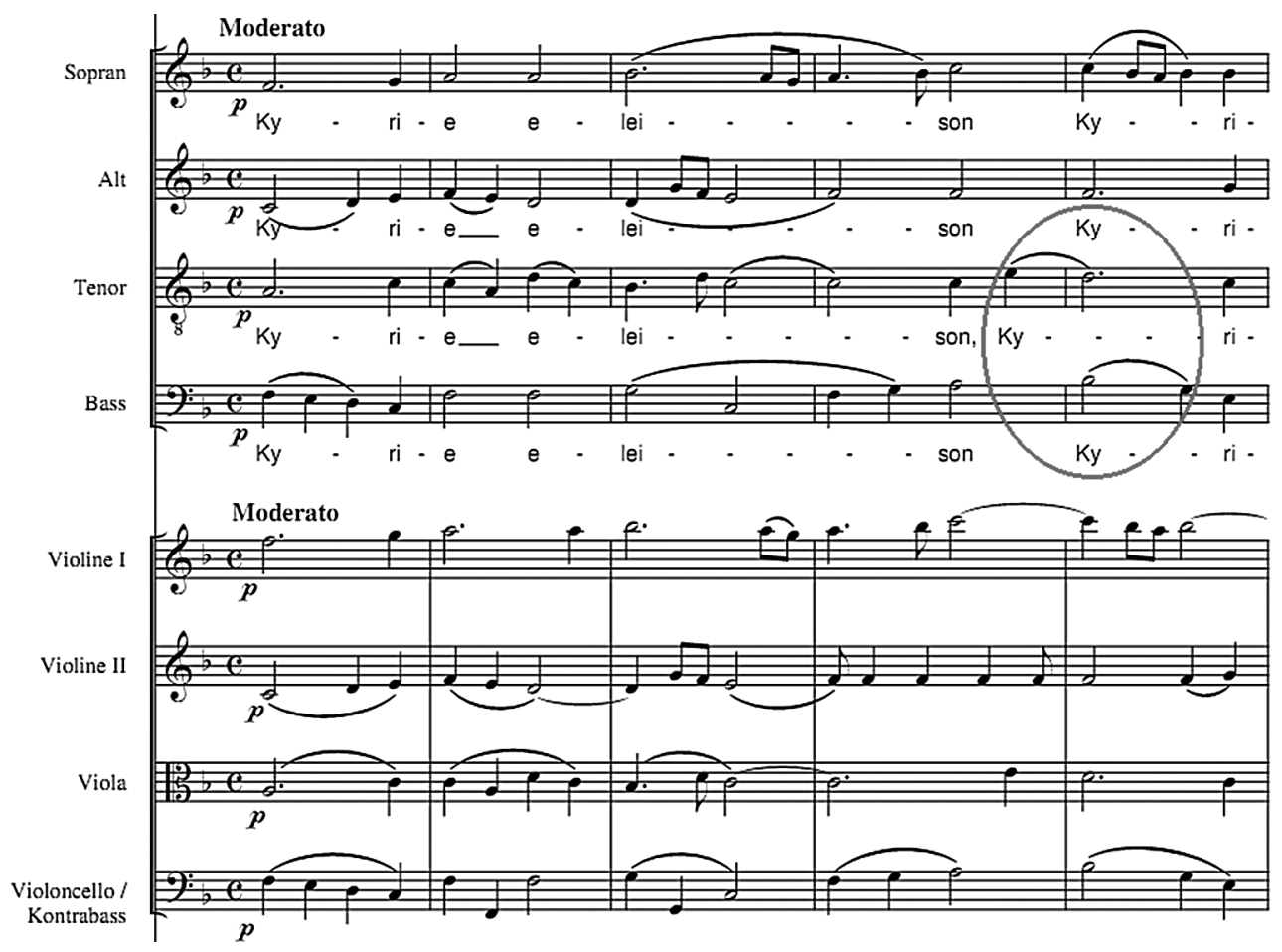

1. kottapélda. Bertha Brukenthal: Missa Solemnis in F, op 7-Kyrie, 1-5 ü.

Megfigyelhető tehát, hogy a vonósok csak megkettőzik (egyes szólamok esetében oktávval) a kórus szólamait, az egyetlen kizökkentő ritmuselem a negyedik ütem szinkópája. A zenei diskurzus folyamán a szerző a kifejezés terét dinamikusabbá teszi azáltal, hogy a kórus és a zenekar külön ritmikai szintjeit hangsúlyozza. Negyedekből és hosszabb értékekből áll a kórusletét, míg a kísérő szólam nyolcadokból és szinkópás ritmussejtekből építkezik. Különleges hanghatást jelent a Christe szegmens, amely a capella pillanatban jelenik meg. A maximális intenzitás a középső szekció végére valósul meg, a hegedúk pontozott ritmusa és a kórus által ismételt zenei motívum (a 28-32. ütem) által. A zenei elemek homogén jellegét az azonos motívumanyag és a zenei anyag egyszerủ, de kifejező használata adja. A forma szerkezetét a következő táblázat mutatja be: 


\begin{tabular}{|l|c|c|c|c|c|c|c|}
\hline Rész & \multicolumn{2}{|c|}{ Kyrie 1-18 ü. } & \multicolumn{2}{|c|}{ Christe 19-32 ü. } & \multicolumn{3}{|c|}{ Kyrie 33-48 ü. } \\
\hline Frázis & $4+4$ ü. & $4+6$ ü. & 4+6ü. & 2+3ü. & 4+4 ü. & 7 ü. & Coda 2 ü. \\
\hline Ütemek & $1-8$. & $9-18$. & $19-27$. & $28-32$. & $33-40$. & $40-46$. & $47-48$. \\
\hline Hangnem & $\mathrm{F}$ & $\mathrm{F}$ & $\mathrm{C}$ & $\mathrm{C}$ & $\mathrm{F}$ & $\mathrm{F}$ & $\mathrm{F}$ \\
\hline
\end{tabular}

2. táblázat. Bertha Brukenthal: Missa Solemnis - Kyrie (szerkezet)

A Gloria liturgikus szövege hosszabb ugyan, de a zeneszerző nem dolgozta fel a maga teljességében, ugyanis egyes részeket elhagyott, a következőképpen:

\section{Missale Romanum ${ }^{10}$}

Glória in excélsis Deo

et in terra pax homínibus bonae voluntátis. Laudámus te, benedícimus te, adorámus te, glorificámus te, grátias ágimus tibi propter magnam glóriam tuam, Dómine Deus, Rex cæléstis, Deus Pater omnípotens. Dómine Fili Unigénite, Iesu Christe, Dómine Deus, Agnus Dei, Fílius Patris, qui tollis peccáta mundi, miserére nobis; qui tollis peccáta mundi, súscipe deprecatiónem nostram. Qui sedes ad déxteram Patris, miserére nobis.

Quóniam tu solus Sanctus, tu solus Dóminus, tu solus Altíssimus, Iesu Christe, cum Sancto Spíritu: in glória Dei Patris. Amen.

\section{Bertha Brukenthal: Missa Solemnis}

Glória in excélsis Deo

et in terra pax homínibus bonae voluntátis. Laudámus te, benedícimus te, adorámus te, glorificámus te, grátias ágimus tibi propter magnam glóriam tuam, Dómine Deus, Rex cæléstis, Deus Pater omnípotens. Dómine Fili Unigénite, Iesu Christe, Dómine Deus, Agnus Dei, Fílius Patris,

Quóniam tu solus Sanctus, tu solus Dóminus, tu solus Altíssimus, Iesu Christe, cum Sancto Spíritu: in glória Dei Patris. Amen.

\section{3. táblázat. A Gloria rész liturgikus szövegeinek összehasonlitása}

Amint megfigyelhető, a közbelső rész - amelyben a bűnök bocsánatát áthatja az örök élet diadala - Bertha Brukenthal művében teljességgel hiányzik.

A Gloria, az istenség magasztalásának zenei kifejezése, energikus tétellel kezdődik, ez pedig olyan harmóniai fokozásra épül, amelyben a tetőpont az excelsis szó elhangzásával esik egybe. A Gloria kifejezés erőteljes profilú, homofon felkiáltás, amelyet a zenekar visszhangoz, valamint a melodikus vonal íve, amely az excelsis tetőpont felé vezet, számos hasonló jellegű alkotás stíluseleme (például Ruzitska György: Missa nr. 5, Joseph Haydn: Theresienmesse). Logikusan következik ebből az első bevezetésből a zenei kontrasztelem a következő mondatban: et in terra pax, ez pedig a piano dinamikának és a szólamok szűk vezetésének köszönhető. A kórusszólam állandó homofon jellege kiemeli a liturgikus szöveg sűrű, sokrétű és megszentelt jellegét.

A vonószenekari kíséret szerepe, hogy a zenei bemutatást a kórus és a zenekar között létrejövő poliritmia révén dinamikusabbá tegye. Azáltal, hogy a szerző a kürtpárt a trombiták hangzásával helyettesítette, kifejezésbeli változatosság jön létre, és a zenei jelleg a rész szakrális üzenetéhez közelebb álló lesz. Ugyanezt a vonást erősíti a timpanik közbelépéséből származó hangszínbeli különbség. A hegedűkíséret ritmikai sűrűsége csökken az $\mathrm{A}-\mathrm{B}$ szegmens-

$11^{* * *}$ Missale Romanum. Editura Typica, Roma, 1967. 501. 
ben, a tizenhatodok használatával kezdődik (az 1-22. ütemnél), nyolcadokkal folytatódik (23-47.), és negyedekkel, illetőleg félértékekkel zárul (48-59.), ezzel az eljárással pedig a kezdőtémához való visszatérés zenei kontraszthatással jár. E rész a következőképpen épül fel:

\begin{tabular}{|l|c|c|c|c|c|c|c|c|}
\hline Rész & \multicolumn{2}{|c|}{ A 1-23 ü. } & \multicolumn{3}{|c|}{ B 24-59 ü. } & \multicolumn{3}{c|}{ Av 60-81 ü. } \\
\hline Frázis & $6+7$ ü. & $4+4 / 2$ ü. & $4 / 4+4 / 4$ ü. & $4 / 4+4 / 4$ ü. & 4 ü. & $6+6$ ü. & $4+4$ ü. & $\begin{array}{c}4+4 / 2 \text { ü. } \\
\text { (Coda) }\end{array}$ \\
\hline Ütemek & $1-13$. & $14-23$. & $24-39$. & $40-55$. & $56-59$. & $60-65$. & $65-72$. & $73-81$. \\
\hline Hangnem & C & C & C a & a & a C & C & C & C \\
\hline
\end{tabular}

4. táblázat. Bertha Brukenthal: Missa Solemnis - Gloria (szerkezet)

Ami a Gloria részt figyelemre méltóvá teszi, az a C-dúr hangnem és a kórus homofon előadásmódjának köszönhető fényteli és diadalmas jelleg. A liturgikus szöveg hiányosságát olyan elemek pótolják némileg a zenei kifejezés szintjén, mint a késleltetések és a kórus meg a zenekar váltakozó megszólalása. A Credo rész a műfajban kísérletező zeneszerző számára valóságos próbakő: egyrészt a szakrális tartalom tematikai összetettsége miatt, másrészt azért, mert a többi részhez képest némileg aránytalan. A zenei diskurzus megvalósítása érdekében különböző zeneszerzői technikákhoz szoktak folyamodni, mint amilyen a politextualitás túlzott használata vagy egyes versek elhagyása. Beszédes példa a politextualitásra Joseph Haydn Missa Sti Joannis de Deójának eredeti formája, a szövegrövidítés pedig többek között Ruzitska György, Bertha Brukenthal, Joseph Preindl, Robert Führer és a 19. század második fele több más zeneszerzője miséinek jellemzője. Bertha Brukenthal Missa Solemnisében a következő szöveghasználat érvényesül:

\section{Missale Romanum ${ }^{11}$}

Credo in unum Deum, Patrem omni potentem, factorem caeli et terrae, visibilium omnium et invisibilium. Et in unum Dominum Iesum Christum, Filium Dei unigenitum,

et ex Patre natum ante omnia saecula. Deum de Deo, lumen de lumine, Deum verum de Deo vero, genitum, non factum, consubstantialem Patri: per quem omnia facta sunt.

Qui propter nos homines et propter nostram salutem descendit de caelis.

Et incarnatus est de Spiritu Sancto ex Maria Virgine, et homo factus est.

Crucifixus etiam pro nobis sub Pontio Pilato; passus et sepultus est.

Et resurrexit tertia die, secundum Scripturas. Et ascendit in caelum, sedet ad dexteram Patris.
Bertha Brukenthal: Missa Solemnis

Credo in unum Deum, Patrem omnipotentem, factorem caeli et terrae, visibilium omnium et invisibilium. Et in unum Dominum Iesum Christum, Filium Dei unigenitum,

Deum de Deo, lumen de lumine, Deum verum de Deo vero, genitum, non factum consubstantialem Patri: per quem omnia facta sunt.

Et incarnatus est de Spiritu Sancto ex Maria Virgine, et homo factus est.

Crucifixus etiam pro nobis sub Pontio Pilato; passus et sepultus est.

Et resurrexit tertia die, secundum Scripturas. Et ascendit in caelum, sedet ad dexteram Patris.

12 Uo. 
Et iterum venturus est cum Gloria, iudicare vivos et mortuos, cuius regni non erit finis. Et in Spiritum Sanctum, Dominum et vivificantem: qui ex Patre Filioque procedit. Qui cum Patre et Filio simul adoratur et conglorificatur: qui locutus est per profetas.

Et unam, sanctam, catholicam et apostolicam Ecclesiam.

Confiteor unum baptisma in remissionem peccatorum.

Et expecto resurrectionem mortuorum et vitam venturi saeculi. Amen.

Et unam, sanctam, catholicam et apostolicam Ecclesiam.

Et expecto resurrectionem mortuorum et vitam venturi saeculi. Amen. Amen.

\section{5. táblázat. A Credo rész liturgikus szövegeinek összehasonlitása}

Ahogyan a fenti szövegek egybevetéséből is kiderül, a harmadik rész jelentős hányada hiányzik. Az időtartamot illetően az első és az utolsó rész tartama hasonló, metrikája azonban különbözik: négy negyed/három negyed és az ütemek száma 40/48.

E rész éthosza a keresztény ember bizalmának határozottságát és bizonyosságát fejezi ki, az érzelmek zenébe transzponálódnak. A szerkezet egészét alkotó periódusok világossága és egyensúlya, továbbá a homofon technika határozottsága szolgál eszközül az alkotó számára az érzelmek fölvázolásához. Az első negyven ütem tartalmazza a Credo részt, amelyben a kórus a liturgikus szöveget pontosan előadja, a kíséret szintjén pedig néhány motivikus egységet azonosithatunk, amelyek a zenei periódusok függvényében változnak. Noha ezen első rész zárlatában a melodikus-harmonikus vonal ereszkedő irányú, amely tendencia a középrészt megelőző szavaknak is jellemzőjük (descendit de coelis), a zeneszerző ebből a részből elhagyja a liturgikus szöveget és a részlet az omnia facta sunt szavakkal zárul.

A legkifejezőbb rész a formális makrostruktúra szimmetriapontján jelenik meg: Et incarnatus - Crucifixus. Az eredeti hangzások kombinációs lehetőségei és a motívumképlet, amelyek jelentése megfeleltethető a szövegnek, nemcsak ennek a résznek az elemei, hanem a mű egésze tekintetében bővítik a tartalmakat. A G-dúr/g-moll hangnemi váltás hatása, valamint az a capella megszólaltatás rezonanciája mind közrejátszik abban, hogy a részt stiláris kontraszt révén elhatárolja a többitől. Az a két liturgikus-zenei téma, amelyek a szöveget alkotják, dinamikájukban, illetőleg a kíséret ritmikai elemei tekintetében kölönböznek. A letét a zenekari hangszín eléréséért először is (a 45-52. ütemekben) nyolcad szünet után a három nyolcad képletet használja, később a Crucifixus szövegére a ritmus szintje dinamikusabb lesz azáltal, hogy a kórus hangzására rátevődnek a szinkópák, amint a 2. kottapélda is mutatja.

Élet és halál küzdelmének drámaiságát a timpani és a trombita közbeszólása növeli, a gesztus a keresztre feszítés végleges történését jelzi előre, a Megváltó büneinkért való halála révén (et sepultus est).

Az utolsó rész (a 63-111. ütem) a feltámadás örömének (et resurrexit) közlésével kezdődik a kórus unisono stílusjegyével, ez a tény kifejezésbeli egyezést mutat ennek szimbolikus üzenetével. A hármas lüktetés mozgalmassá és gördülékenyebbé teszi a zenei hangzást, megkönnyíti a vokális előadást is. Az Apostoli hitvallás egy teljes szövegegységnyi mondatainak elhagyása azonban, sajnos, csökkenti e rész szakrális kifejezőértékét. Ugyanaz a szinkópás ritmuselem, amely a Crucifixus jellemzője volt, a szöveg bemutatásakor hasonló jelentésben 
szerepel: mortuorum. Ha a két részt egybevetjük, nyilvánvalók a hasonlóságok (2. és 3. kottapélda).

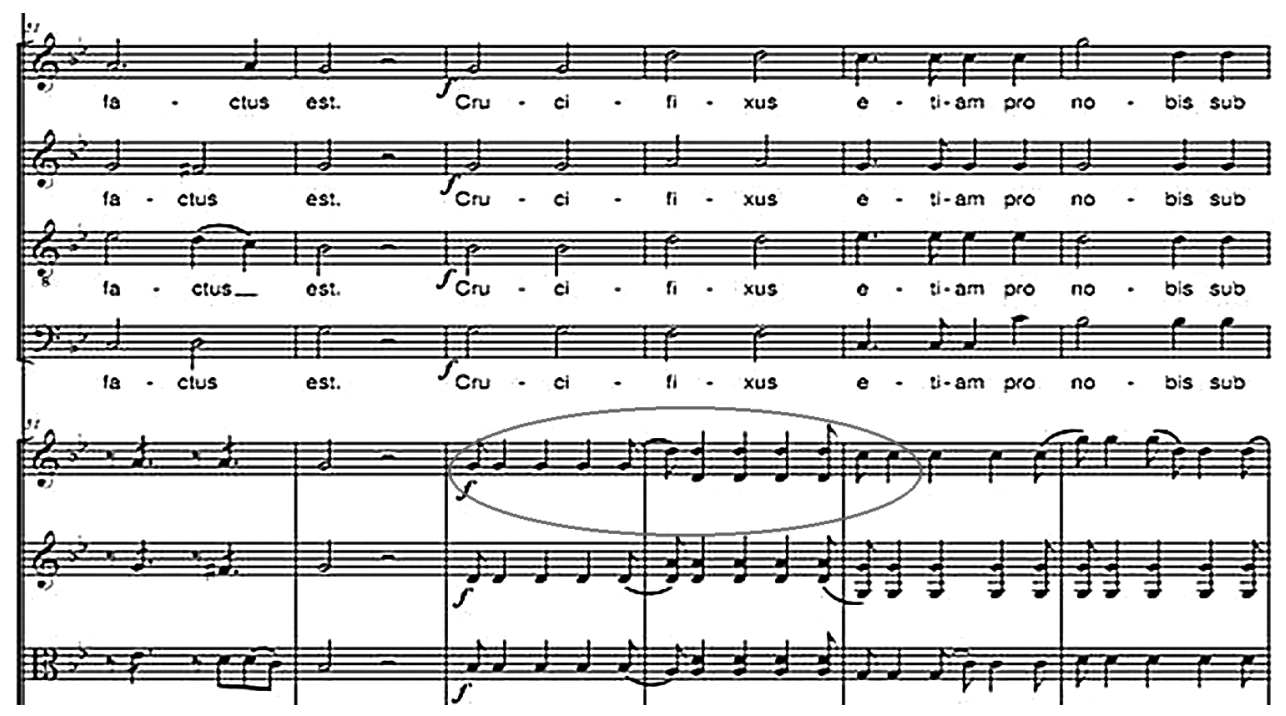

2. kottapélda. Bertha Burkenthal: Missa Solemnis in F, op. 7 -Credo, 51-56. ü.

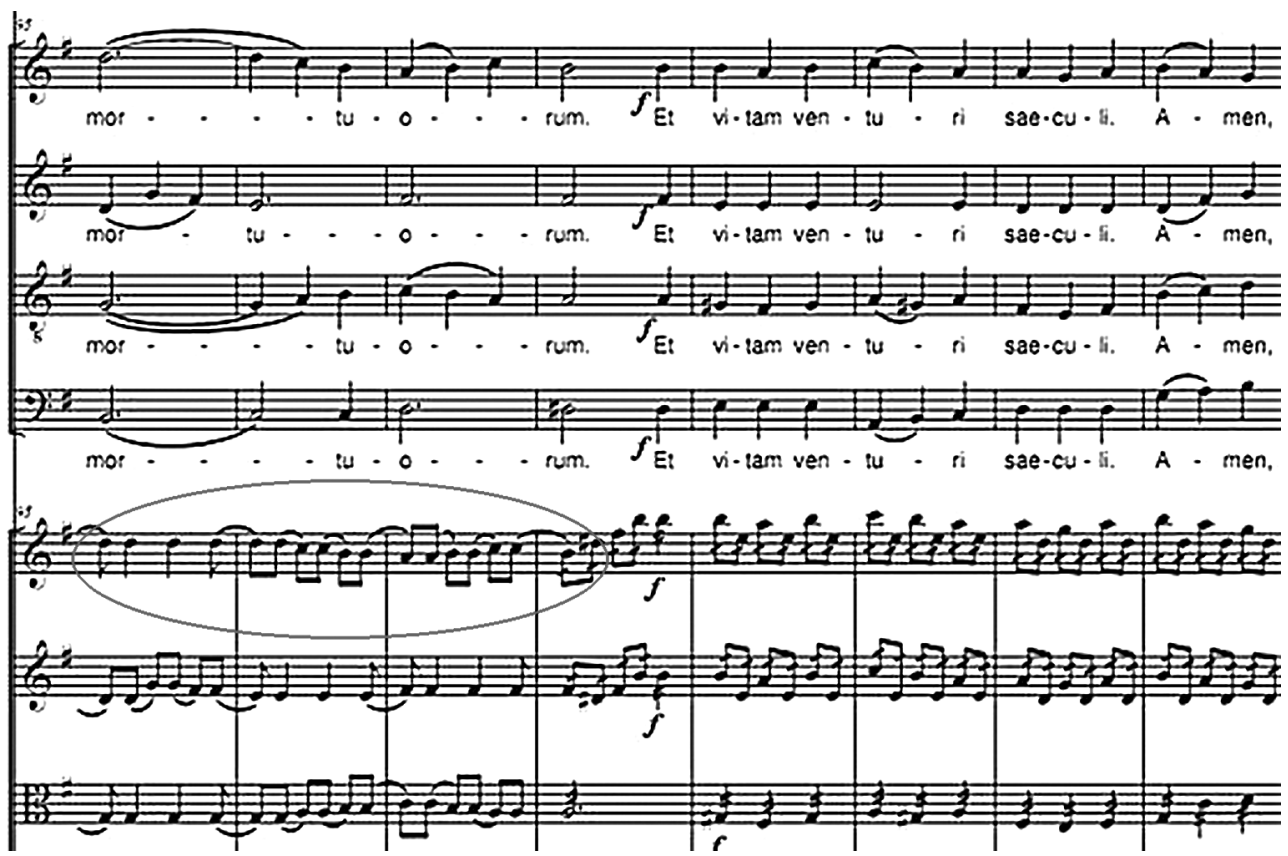

3. kottapélda. Bertha Brukenthal: Missa Solemnis in F, op 7 - Credo, 95-102. ü. 
A dinamikus teret a piano és a forte hangerők árnyalatainak váltakozása határozza meg, de az esetek többségében ez természetes módon következik a melodikus vonal jellegéből és a szöveg jelentéséből. A harmóniai menet az alap, G-dúr tonalitás rokon hangnemeibe való inflexiókkal tarkított, célja, hogy a szöveg egyes részleteit érvényre juttassa. E rész kódáját kilencütemnyi, lefelé ívelő melodikus-harmonikus elem adja, melynek szövege Amen, az első hegedű arpeggio-jellegű motívum révén ismétli a hozzá tartozó akkordláncot. Az alábbi táblázatban foglaltak szerint a háromtagú Credo részt a következők jellemzik:

\begin{tabular}{|l|c|c|c|c|c|c|c|c|c|}
\hline Rész & \multicolumn{4}{|c|}{ A1-40 ü. } & \multicolumn{2}{c|}{ B 41-62 ü. } & \multicolumn{3}{c|}{ C 63-111 ü. } \\
\hline Frázis & $4+6$ & $4+5$ & $4+4$ & $4+4 / 4$ & $4+4 / 4$ & $6+4$ & $8+6 / 4$ & $4 / 4+8+4$ & Coda 4+5 \\
\hline Ütemek & $1-10$. & $11-19$. & $20-27$. & $28-40$. & $41-52$. & $53-62$. & $63-80$. & $81-102$. & $103-111$. \\
\hline Hangnem & G D & D & G & G & $\mathrm{g}$ & $\mathrm{g}$ & $\mathrm{G}$ & $\mathrm{C}$ & $\mathrm{G}$ \\
\hline
\end{tabular}

6. táblázat. Bertha Brukenthal: Missa Solemnis - Credo (szerkezet)

A Credo rész a zenei kifejezéstár azon elemeit használja, amelyek ennek koherens és áttetsző szellemével egyezőek. Azok az esztétikai értékek, amelyek e mozgás középső metszetének zenéjének formát adnak, hangolják össze a zenei kifejezés valamennyi elemét a liturgikus szöveg jelentésének pontos zenei megfogalmazása érdekében.

A Sanctus részt egységes elképzelés határozza meg, a pleni sunt fragmentum belső elhatárolása nélkül. A kórusletét homofon jellege állandó, az újdonságelemet a pontozott ritmus jelenti, amely a vonósok szintjén állandósul. A hármas lüktetés és gyorsabb tempó mozgékonnyá teszi a zenei diskurzust, megkönnyítve ezzel a magas regiszterben a szoprán és a tenor szólamok esetében a hangok intonálását. A trombiták és timpanik belépésének sűrűsége győzedelmes és magasztos jelleget ad a tételnek. A dallamív felépítése a szöveg értelmezését is tükrözi, példa erre a coeli (ég) és excelsis (menny) szavak magas regiszterű intonációja.

Ez a rész 36 ütemből áll, a szövegelosztás tekintetében két nagy zenei periódussal számolhatunk: a Sanctus (20 ütem) és az Osanna (16 ütem). Anton Hubatschek és Ruzitska György misekompozícióihoz hasonlóan Bertha Brukenthal a szó olasz formáját használja: az Osanna terminust a Hosanna helyett. A következő táblázat e rész formai jellemzői mutatja be:

\begin{tabular}{|l|c|c|c|c|}
\hline Rész & \multicolumn{4}{|c|}{ Sanctus } \\
\hline Frázis & $4+4$ ü. & $6+6 \ddot{\text { u. }}$ & $4+4$ ü. & $4+4$ ü. \\
\hline Ütemek & $1-8$. & $9-20$. & $21-28$. & $29-36$. \\
\hline Hangnem & $\mathrm{C}$ & $\mathrm{C}(\sim \mathrm{a})$ & $\mathrm{C}$ & $\mathrm{C}$ \\
\hline
\end{tabular}

7. táblázat. Bertha Brukenthal: Missa Solemnis - Sanctus (szerkezet)

A Benedictus rész liturgikus keretben való bemutatásának problematikus volta a korábbi részhez mért aránytalanságából adódik (Sanctus - 36 ütem, Benedictus - 56 ütem). A Sanctus és Benedictus rész egymást követő (a liturgikus rend szerinti) bemutatása az énekelt vagy elmondott szövegek között nem kívánatos megszakítással járna. Javasoljuk e rész előadását például a szentáldozás idején.

A sílus vonatkozásában ez a megoldás az első résszel mutat rokon vonásokat, gyöngéd és lírai jellege miatt, amely F-dúr hangzásban valósul meg és az I. hegedű artikulációjának köszönhetôen, amely a zenei tételek legnagyobb részét legatóban közvetíti. 
E rész teljes szövege a Benedictus, qui venit in nomine Domini. Osanna in excelsis, a mú utolsó mondata azonban nem került be a megharmonizált kifejezések sorába. Ez nem csak az elemzett mise jellemzője, hasonló esetek jelennek meg Anton Hubatschek első miséjében és más, hasonló múfajú alkotásokban. A mozzanat formája a következő:

\begin{tabular}{|l|c|c|c|c|c|c|c|}
\hline Rész & \multicolumn{2}{|c|}{ A1 1-18 ü. } & \multicolumn{2}{c|}{ A2 19-35 ü. } & \multicolumn{2}{c|}{ C 36-49 ü. } & coda 50-58 ü. \\
\hline Frázis & $4+4$ & $4+4$ & $4+4$ & $4+4+1$ & $4+4$ & $3+3$ & $5+4$ \\
\hline Ütemek & $1-8$. & $9-18$. & $19-26$. & $27-35$. & $36-43$. & $44-49$. & $50-58$. \\
\hline Hangnem & $\mathrm{F}(\sim \mathrm{a})$ & $\mathrm{F} \sim \mathrm{d}$ & $\mathrm{d}$ & $\mathrm{d} \sim \mathrm{F}$ & $\mathrm{F}$ & $\mathrm{F}$ & $\mathrm{F}$ \\
\hline
\end{tabular}

8. táblázat. Bertha Brukenthal: Missa Solemnis - Benedictus (szerkezet)

Amint megfigyellhető, a frázisok kiegyensúlyozott szerkezete állandó marad a zenei folyamat egészében, ez pedig a szerző kifejezésbeli koherenciáját és alapos zenei felkészültségét bizonyítja. A Benedictus rész különleges zenei momentum, a fokozott érzelmi értékủ vokális kifejezésmód révén, nagyobb részét szólistákból álló együttes is előadhatná.

A mise középrészének Credo tételében előforduló hangnemek dúr és moll közti váltakozásával kezdi a szerző az Agnus Deit is. A Kyriehez hasonló jelképiség, továbbá az f-moll jellegzetes hangzása jelentik a hanghatás meghatározó elemeit. Két résszel (Agnus és Dona nobis pacem) számolva, a zeneszerző ugyanazon szöveg harmonizálását a Kyrie utolsó részének anyagát újra felhasználva végzi: Dona nobis pacem. Ez a szerkezeti elem egy katrénhoz hasonló különleges és stabil stílusegység jegyeit mutatja, kiemelve ismételten a két rész közös elemeit. A három kijelentés, amely az áldozat kifejezésének törzsét alkotja, az első részbelihez hasonló módon valósul meg, eredeti módon emelve ki a zenekar némileg erőteljesebb szerepét. Azokat a momentumokat, ahol a kórus a miserere szövegrészt adja elő, a hangszerek mintegy visszhangként követik, így a két előadási szint egyformán fontossá válik. A búnbocsánatért való könyörgés bensőséges jellegủ hangja sajátos ellentétben áll a vonósok pontozott ritmusú és a fúvósok, illetve a dobok által megkettőzött energikus válaszával (4. kottapélda).

Az értelmezésben említett néhány stíluselem különösen Ruzitska György miséiben lelhető fel, például ez az első misében található vokálszimfonikus dialógus.

Az Agnus Dei szerkezeti formáját vizsgálva a következő konklúziókat fogalmazhatjuk meg:

\begin{tabular}{|l|c|c|c|c|c|}
\hline Rész & $\mathrm{A}$ & $\mathrm{A}$ & $\mathrm{Av}$ & $\mathrm{B}$ & coda \\
\hline Frázis & $4+4$ & $4+4$ & $4+4 / 4$ & $4+4 / 6$ & 2 \\
\hline Ütemek & $1-8$. & $9-16$. & $17-28$. & $29-42$. & $43-44$. \\
\hline Hangnem & $\mathrm{F}$ & $\mathrm{f}$ & $\mathrm{f}$ & $\mathrm{F}$ & $\mathrm{F}$ \\
\hline
\end{tabular}

9. táblázat. Bertha Brukenthal: Missa Solemnis - Agnus (szerkezet) 


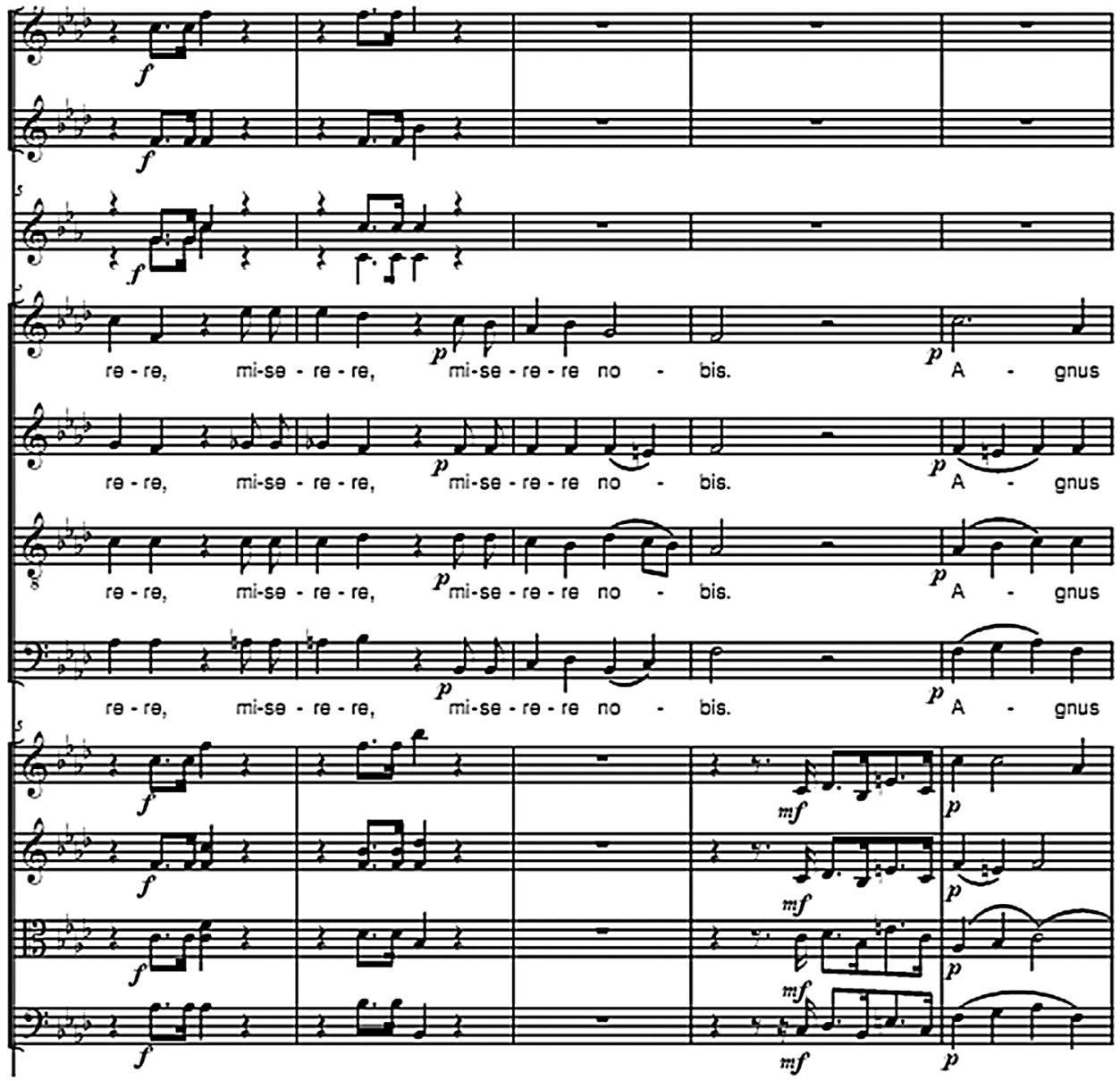

4. kottapélda. Bertha Brukenthal: Missa Solemnis in F, op 7 -Agnus, 5-9. ü.

Megjegyezzük, hogy a misének ez az egyetlen olyan része, amelyben egy zenei periódus az első 16 ütemben megismétlődik. Az A és B rész jellege közötti kontraszt részben a különböző agogikának tudható be, részben pedig a bűnbocsánatért és a lélek nyugalmáért való könyörgés jelentéstartalmának (miserere, illetve dona nobis pacem).

Bertha Brukenthal op. 7-es Missa Solemnise sikeres kísérlet a zenei klasszicizmus zeneszerzési elemeinek felidézésére. Noha a teljes szöveg harmonizálási szintjén a Gloria és Credo részeket illetően hiányosságokat mutat, és a mű egészének zeneszerzési szempontból jobbára egyszerűsítő a jellege, a szövegjelentésből adódó sajátosságok kétségtelenül fellelhetők a zenében. 


\section{BERTHA BRUKENTHAL: AN ARISTOCRAT AMONG THE TRANSYLVANIAN COMPOSERS}

\section{Keywords: Bertha Brukenthal, Transylvania, ecclesiastical music, Cecilian Music movement, Missa Solemnis in F major}

Member of the Transylvanian aristocracy, Bertha Brukenthal (1846, Vienna - 1908, Gainfarn im Baden) distinguished herself as a composer. The baroness dedicated most of her works to the members of the Viennese, Saxon and the Hungarian nobility, thus consolidating and promoting family and social connections. Her oeuvre consists of 25 compositions: lieds, chamber music and ecclesiastical works the laters strongly connected to the Cecilian Music movement. Completed probably in Transylvania in 1871, the clear and accessible style of the F major Missa Solemnis can be viewed as an eloquent example for the influence of the Roman Catholic church music reform in the eastern part of Europe.

\section{BERTHA BRUKENTHAL: O ARISTOCRATĂ ÎN PEISAJUL COMPONISTIC AUTOHTON}

\section{Cuvinte-cheie: Bertha Brukenthal, Transilvania, compoziții eclesiastice, cecilianism, Missa Solemnis în Fa major}

Membră a aristocrației din Transilvania, Bertha Brukenthal (1846, Viena - 1908, Gainfarn im Baden) s-a remarcat prin activitatea sa de compozitor. Baroana a dedicat majoritatea pieselor sale membrilor nobilimii vieneze, sau celei de origine săsească sau maghiară, consolidând și promovând astfel relații familiale și sociale. Opera ei muzicală include 25 de compoziții: lieduri, muzică de cameră și muzică bisericească - aceasta din urmă fiind strâns legată de mișcarea ceciliană. Finalizată în 1871, probabil în Transilvania, stilul clar și accesibil al Missei Solemnis poate fi perceput drept un exemplu elocvent privind influența reformei muzicii eclesiastice romano-catolice în partea de Est a Europei.

\section{KÉPJEGYZÉK/LIST OF ILLUSTRATIONS/LISTA ILUSTRAȚIILOR}

1. Bertha Brukenthal (1846-1909)

2. Hermann Brukenthal (1843-1872)

3. Haynald Lajos (bal szélen, ül), Liszt Ferenc és más személyiségek körében/Lajos Haynald (on the left, sitting) with Franz Liszt and acquintances/Lajos Haynald (în partea stângă, șezând) în cercul lui Franz Liszt 